\title{
A literature Survey on Well-known Algorithms of Optimum Power Flow
}

\author{
Baqer Atiyah Allamey ${ }^{1}$, Falah Jaber Kshash ${ }^{2}$, Warid Warid ${ }^{3}$ \\ \{dr.baqer_turki@stu.edu.iq ${ }^{1}$, hhs.falah@gmail.com ${ }^{2}$, warid.sayel@stu.edu.iq ${ }^{3}$ \}
}

Southern Technical University, Basra, Iraq ${ }^{1,2,3}$

\begin{abstract}
One of the most often researched non-linear optimization issues is the optimal power flow (OPF) problem. The performance of electricity production, transmission, and distribution must be improved under a variety of system needs and control restrictions in general (OPF). The compositions of OPFs and the methods used to apply them are quite diverse. Furthermore, as a result of recent power markets and the absorption of renewable resources, the character of OPF is evolving. Various OPF formulations have been dealt with using a variety of classical and meta-heuristic methods throughout the last three decades. This survey explores both traditional and intelligent OPF approaches to provide a strong background for the present status of OPF formulations and solutions approaches. The survey covers all of the optimization approaches that researchers have used to (OPF), with a focus on the advantages and disadvantages of each method for both traditional and intelligent OPF methods.
\end{abstract}

Keywords: Optimal Power Flow (OPF), classical Optimization methods, metaheuristic algorithm Optimization.

\section{Introduction}

Since Carpentier initially published a paper in 1962, the optimal power flow (OPF) problem has been one of the most extensively studied problems in power system operation. The goal of OPF formulation is to arrive at a steady-state solution that reduces generating costs, system losses, or optimizes societal welfare or system utilization, among other things while maintaining acceptable performance of the system active and reactive power constraints on generators, line flow limitations, and a maximum output of different compensating devices...etc. The generic OPF problem is a large-scale, non-convex, nonlinear optimization problem with both continuous and discrete control variables. Several OPF formulations have been created to solve specific examples of the problems, each with its own set of assumptions and choices of objective functions, system limitations, and controls. Generally, the OPF approach is frequently applied to several industrial applications such as restricted economic dispatch and voltage control problems [1]. In this survey, the OPF methods are broadly classified as conventional and intelligent methods. Solution methodologies can broadly be categorized into two groups: classical methods; several traditional methods used for solving OPF problems such as the Newtonian technique grid flow programming, linear programming, nonlinear programming, quadratic programming, and the interior point method. As the main shortcoming, these traditional methods are not suitable for large and difficult OPF problems. Because the 
optimization framework is non-linear and multimedia in nature, these approaches may become trapped in local solutions. Traditional approaches are based on diverse mathematical programming frameworks and are used to answer a variety of sizes of OPF issues in order to meet the requirements of various objective functions, application types, and constraint natures. Traditional methods are inadequate for dealing with qualitative constraints. These approaches have weak convergence, can only identify one optimum solution in a single simulation run, become excessively slow when the number of variables grows big, and are computationally expensive when addressing a large system.. Intelligent methods; many meta-heuristic methods were used to solve OPF such as genetic algorithm (GA), particle swarm optimization (PSO), artificial neural network (ANN), bee colony optimization (BCO), differential evolution (DE), grey wolf optimizer (GWO), shuffled frog-leaping (SFL) and fuzzy logic (FL) method. Recently, to overcome the shortcomings of conventional methods, many intelligence optimization techniques based on various concepts such as evolutionary inspired algorithms, human-inspired algorithms, and naturally inspired algorithms were implemented to solve the OPF formulation. The main advantages of meta-heuristic optimization techniques are that they are relatively flexible in dealing with different qualitative constraints. As a result, they are well suited for solving multi-objective optimization problems. In most cases, they could also find the global optimal solution. It also has learning capability, is fast in convergence, and is suitable for non-linear modeling. However, there are some drawbacks such as high dimensionality and the selection of training methods [2]. In this article, the form of a table is used to review the scientific contributions of each method with its advantages and disadvantages. Also, a summary to review the conclusions is given.

\section{Optimal Power Flow Methods}

The traditional and modern optimization techniques that have been used to solve the OPF problem are depicted in Fig 1.

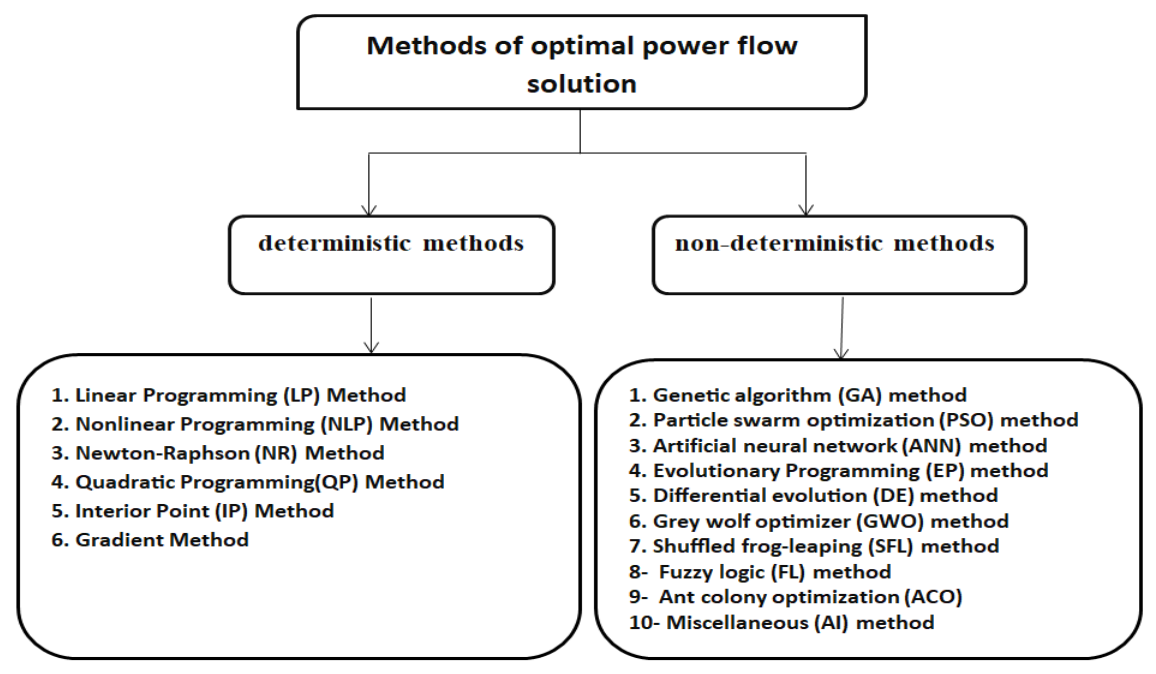

Fig. 1. Optimal Power Flow Solution Methods. 


\subsection{Classical Methods (Deterministic Methods)}

\subsubsection{Linear Programming (LP) Method}

Several academics have used linear programming to tackle many problems involving optimal power flow. Linear programming formulation necessitates the linearization of the goal function as well as nonnegative variable constraints. Several nonlinear power system optimization issues are linearized using various linear programming-based methodologies [3]. In Table 1, the most important scientific contributions in this field were explained:-

Table 1. The LP approaches are used for solving the OPF problem.

\begin{tabular}{|c|c|c|c|c|}
\hline $\begin{array}{l}\text { Ref. } \\
\text { No. }\end{array}$ & year & $\begin{array}{l}\text { objective } \\
\text { function }\end{array}$ & system & Scientific contribution \\
\hline$[4]$ & 1996 & $\begin{array}{l}\text { the optimal cost } \\
\text { and benefit. }\end{array}$ & $\begin{array}{l}14 \text { bus } \\
\text { system }\end{array}$ & $\begin{array}{l}\text { provided a recursive linear programming- } \\
\text { based method for reducing line losses and } \\
\text { determining the best capacitor allocation in a } \\
\text { distribution system. }\end{array}$ \\
\hline$[5]$ & 2001 & $\begin{array}{l}\text { transmission losses } \\
\text { and generator } \\
\text { reactive outputs }\end{array}$ & $\begin{array}{l}\text { the French, } \\
\text { Portuguese, } \\
\text { and } \\
\text { Moroccan } \\
\text { systems. }\end{array}$ & $\begin{array}{l}\text { The method proposed is an iterative approach } \\
\text { in which the objective function and } \\
\text { constraints are linearized in each iteration. A } \\
\text { set of tangent cuts is also used to represent } \\
\text { the objective function.. }\end{array}$ \\
\hline [6] & 2003 & $\begin{array}{l}\text { determines the } \\
\text { number, position, } \\
\text { and settings of } \\
\text { phase shifters in a } \\
\text { network. maximize } \\
\text { system load ability }\end{array}$ & $\begin{array}{l}\text { the IEEE 24-, } \\
118-\text {, and } \\
\text { 300-bus } \\
\text { systems, a } \\
\text { 904-bus } \\
\text { network }\end{array}$ & $\begin{array}{l}\text { A recent mixed-integer linear programming } \\
\text { (MILP) method was used. }\end{array}$ \\
\hline [7] & 1992 & cost optimization & $\begin{array}{l}\text { 5-bus } \\
\text { system }\end{array}$ & $\begin{array}{l}\text { For optimum power flow, a linear } \\
\text { programming-based optimization approach } \\
\text { was presented. }\end{array}$ \\
\hline [8] & 2014 & $\begin{array}{l}\text { generation cost, } \mathrm{P} \\
\text { loss. }\end{array}$ & $\begin{array}{l}\text { Iraqi } 24 \text { bus } \\
(400 \mathrm{kV}) \\
\text { test system. }\end{array}$ & $\begin{array}{l}\text { Linear Programming to cover the target fitness } \\
\text { and constraints in each iteration. }\end{array}$ \\
\hline
\end{tabular}

In summary, we find that linear programming has several advantages and disadvantages which are mentioned briefly as follows:

\section{Advantages:}

1. The LP approach can easily deal with nonlinearity constraints.

2. It is effective in dealing with inequalities and it has a good convergence characteristic.

3. Efficiently handles local constraints.

4. It is capable of incorporating contingency constraints. 


\section{Disadvantages:}

1. It suffers a lack of accuracy. Also, it is trapped in local minima.

2. Although LP approaches are quick and dependable, they have several drawbacks due to piecewise linear cost assumptions.

\subsubsection{Nonlinear Programming (NLP) Method}

Nonlinear programming (NLP) is a technique for solving problems with nonlinear goal and constraint functions. The fundamental benefit of NLP formulation for (OPF) is also that they correctly reflect the behavior of power systems. (NLP) techniques employ the reduced gradient technique with the Lagrange multiplier or the penalty function optimization method (2). In Table 2, the most important scientific contributions in this field were explained:

Table 2. The NLP approaches are used for solving the OPF problem.

\begin{tabular}{|c|c|c|c|c|}
\hline $\begin{array}{l}\text { Ref. } \\
\text { No. }\end{array}$ & year & objective function & system & Scientific contribution \\
\hline [9] & 2001 & Losses and cost & $\begin{array}{l}\text { IEEE 30-bus } \\
\text { system }\end{array}$ & $\begin{array}{l}\text { Applied a new nonlinear convex programming } \\
\text { (NLCNFP) model. }\end{array}$ \\
\hline$[10]$ & 2006 & $\begin{array}{l}\text { maximize the } \\
\text { system load ability }\end{array}$ & IEEE 24-bus & $\begin{array}{l}\text { In the deregulated energy markets, a new method } \\
\text { is applied to find the best number and position of } \\
\text { TCSCs utilising a mixed-integer non-linear } \\
\text { programming methodology. }\end{array}$ \\
\hline [11] & 2004 & $\begin{array}{l}\text { minimize active } \\
\text { losses and load } \\
\text { stability }\end{array}$ & $\begin{array}{l}\text { from } \\
30,57,118,300 \\
\text { to } 2098 \text { buses } \\
\text { system }\end{array}$ & $\begin{array}{l}\text { presents and compares the computational } \\
\text { performance of smooth, non-smooth, and } \\
\text { Jacobian smoothing nonlinear complementarity } \\
\text { (NC) methods for solving nonlinear (OPF) } \\
\text { problems. }\end{array}$ \\
\hline [12] & 2002 & $\begin{array}{l}\text { the total cost of } \\
\text { VArs committed or } \\
\text { the overall cost } \\
\text { associated with the } \\
\text { VAr requirement }\end{array}$ & $\begin{array}{l}\text { the IEEE-I } 18 \\
\text { bus system }\end{array}$ & $\begin{array}{l}\text { The characteristics of optimal power flows } \\
\text { (OPFs) based on linear programming (LP) and } \\
\text { nonlinear programming (NLP) are examined. }\end{array}$ \\
\hline$[13]$ & 1970 & $\begin{array}{l}\text { reduction in } \\
\text { computer time, } \\
\text { storage } \\
\text { requirements }\end{array}$ & $\begin{array}{l}\text { the IEEE } \\
14,30,57 \\
\text { and } 118 \text { bus } \\
\text { systems }\end{array}$ & $\begin{array}{l}\text { provides a decomposition methodology that may } \\
\text { be combined with the Fletcher-Powell method to } \\
\text { broaden the nonlinear programming method's } \\
\text { application to huge systems. }\end{array}$ \\
\hline
\end{tabular}

In summary, we find that nonlinear programming has several outcomes as follows:

\section{Advantages:}

1. When compared to linear programming, the nonlinear programming (NLP) method is more accurate since it may be used for nonlinear objective functions and constraints.

2. Can be applied to large-scale problems.

\section{Disadvantage:}

1. some components of the system are not considered. 


\subsubsection{Quadratic Programming (QP) method}

With a quadratic objective function and linear constraints, it is a type of nonlinear programming. In power systems, quadratic programming-based optimization is used to keep a specified voltage profile, maximise power flow, and lower generating costs [1]. In Table 3, the most important scientific contributions in this field were explained:-

Table 3. The QP approaches are used for solving the OPF problem.

\begin{tabular}{|c|c|c|c|c|}
\hline $\begin{array}{l}\text { Ref. } \\
\text { No. }\end{array}$ & year & $\begin{array}{l}\text { objective } \\
\text { function }\end{array}$ & system & Scientific contribution \\
\hline [14] & 1989 & $\begin{array}{l}\text { Voltage } \\
\text { deviation, } \\
\text { cost, and } \\
\text { losses }\end{array}$ & $\begin{array}{l}\text { A 39-bus } \\
\text { system }\end{array}$ & $\begin{array}{l}\text { A generalized optimal power system flow problem } \\
\text { has been formulated using a quadratic form of power } \\
\text { systems. The (OPF) method is built with the } \\
\text { feasibility, convergence, and optimality } \\
\text { requirements in mind. }\end{array}$ \\
\hline [15] & 1998 & $\begin{array}{l}\text { Losses with } \\
\text { many } \\
\text { elements } \\
\text { including } \\
\text { reactive } \\
\text { power. }\end{array}$ & $\begin{array}{l}\text { the IEEE } 30 \\
\text { and } 278 \text { bus } \\
\text { systems }\end{array}$ & $\begin{array}{l}\text { The method of successive quadratic programming } \\
\text { (SQP) was used to develop a reactive power } \\
\text { optimization model. The focus of this study is on the } \\
\text { mathematical elements of reactive power } \\
\text { optimization using the successive QP approach. }\end{array}$ \\
\hline$[16]$ & 2000 & $\begin{array}{l}\text { total } \\
\text { generation } \\
\text { and } \\
\text { transmission } \\
\text { losses }\end{array}$ & $\begin{array}{l}\text { the CIGRE } \\
\text { system and } \\
\text { the Italian } \\
\text { EHV system }\end{array}$ & $\begin{array}{l}\text { For security-constrained economic dispatch, dual } \\
\text { sequential quadratic programming was w } \\
\text { recommended. By minimising transmission } \\
\text { constraints and subsequently punishing constraint } \\
\text { violations, the dual quadratic technique is utilised to } \\
\text { produce a dual viable starting point. It features a } \\
\text { quick calculating time and good precision. }\end{array}$ \\
\hline [17] & 2003 & $\begin{array}{l}\text { voltage } \\
\text { stability and } \\
\text { minimum } \\
\text { reactive cost }\end{array}$ & $\begin{array}{l}\text { the IEEE 14- } \\
\text { bus system. }\end{array}$ & $\begin{array}{l}\text { For competitive marketplaces, a method is proposed } \\
\text { that integrates cost and voltage stability analysis } \\
\text { using an OPF formulation. }\end{array}$ \\
\hline [18] & 2005 & $\begin{array}{l}\text { calculations } \\
\text { of line flows } \\
\text { and real } \\
\text { losses }\end{array}$ & $\begin{array}{l}\text { the CIGRE } \\
\text { 63-bus system } \\
\text { and Italian } \\
\text { EHV network. }\end{array}$ & $\begin{array}{l}\text { proposed SCOPF (security-constrained optimal } \\
\text { power flow) to find the best UPFC and TCPAR } \\
\text { settings and operation modes. The HP (Han-Powell) } \\
\text { algorithm was used to find the solution to the OPF. }\end{array}$ \\
\hline
\end{tabular}

In summary, we find that QP could be summarized by:

\section{Advantages:}

1. In many cases, conditioned and divergent systems are solvable.

2. When compared to other recognized approaches, the accuracy of the QP approach is significantly better.

3. It has fast convergence characteristic.

\section{Disadvantage:}

1. Obtaining solutions to quadratic programming problems in reliable performance of approximating QP problems is difficult. 


\subsubsection{Interior Point (IP) Method}

It's a novel method for computing large-scale linear programming problems quickly. Because it enhances search directions only within the limitations of the possible space, it is referred to as an internal technique. Interior Point Methods (IPMs) are a type of scaling approach that uses projections to solve linear and nonlinear optimization problems [3]. In Table 4, the most important scientific contributions in this field were explained:

Table 4. The IP approaches are used for solving the OPF problem.

\begin{tabular}{|c|c|c|c|c|}
\hline $\begin{array}{l}\text { Ref. } \\
\text { No. }\end{array}$ & year & $\begin{array}{l}\text { objective } \\
\text { function }\end{array}$ & system & Scientific contribution \\
\hline [19] & 2002 & $\begin{array}{l}\text { fuel cost and } \\
\text { power loss } \\
\text { minimization }\end{array}$ & $\begin{array}{l}\text { IEEE } 14 \text { and } 57 \text { buses } \\
\text { standard test systems }\end{array}$ & $\begin{array}{l}\text { presented an independent OPF methodology } \\
\text { with IPBCM approach. }\end{array}$ \\
\hline [20] & 2001 & $\begin{array}{l}\text { cost and } \\
\text { loss } \\
\text { minimization }\end{array}$ & The IEEE 30 and 118 buses & $\begin{array}{l}\text { For optimum power flow problems, new } \\
\text { versions of interior-point techniques were } \\
\text { introduced. A mixture of two approaches, } \\
\text { affine-scaling and centralization, is used to } \\
\text { get the optimal answer. }\end{array}$ \\
\hline [21] & 2005 & $\begin{array}{l}\text { generation } \\
\text { cost and } \\
\text { active power } \\
\text { losses. }\end{array}$ & $\begin{array}{l}\text { Nordic } 32 \text { system , } \\
\text { IEEE118 and IEEE300 } \\
\text { systems }\end{array}$ & $\begin{array}{l}\text { Two interior point (IP) based methods were } \\
\text { compared to address various OPF issues: the } \\
\text { infeasible } 1 \text { pure primal-dual method and the } \\
\text { infeasible primal-dual predictor-corrector } \\
\text { approach. }\end{array}$ \\
\hline$[22]$ & 2006 & $\begin{array}{l}\text { Time, } \\
\text { iterations, and } \\
\text { power losses }\end{array}$ & $\begin{array}{l}\text { IEEE Test Systems with } \\
\text { various buses }\end{array}$ & $\begin{array}{l}\text { A new transformer model is applied by ideal } \\
\text { case and load impedance. }\end{array}$ \\
\hline [23] & 2020 & $\begin{array}{l}\text { the MSE-loss } \\
\text { and total } \\
\text { energy cost }\end{array}$ & The energy price data & $\begin{array}{l}\text { The Linear Programming relaxation was } \\
\text { given a log-barrier term, which makes it } \\
\text { twice differentiable and is the usual } \\
\text { procedure in Linear Programming when } \\
\text { employing interior point methods. }\end{array}$ \\
\hline
\end{tabular}

In summary, we find that IP has unique outcomes such as:

\section{Advantages:}

1. It is one of the most effective algorithms available.

2. high accuracy, high convergence speed and reliability.

\section{Disadvantages:}

1. Due to the starting and ending conditions, there is a constraint.

2. If the step size is selected incorrectly, the solution is infeasible.

Finally, the disadvantages of traditional approaches might be summarized as three main drawbacks:

1. The optimum solution cannot be obtained and are frequently stuck at a local optimum. 
2. All of these approaches are predicated on the assumption of objective function properties in which some of its elements are not attainable.

3. With discrete variables like transformer taps, none of these techniques can be used. It is observed that intelligent techniques are suitable methods to overcome the above drawbacks.

\subsection{Artificial Intelligence (AI) Methods ( Non-Deterministic Methods )}

Intelligent search has become a widely used methodology. Several non-deterministic optimization approaches were discovered to address the global search methods in supporting the deterministic optimization algorithms. Many of these methods, such as the genetic algorithm, particle swarm optimization, artificial neural network, evolutionary programming, differential evolution, grey wolf optimizer, shuffling frog-leaping, fuzzy logic (FL) method, and ant colony optimization, have been utilised to tackle OPF problems. We will briefly mention the scientific contributions made by researchers to some of the methods above:

\subsubsection{Genetic Algorithms}

The genetic algorithm (GA) works with the problem parameters encoded binary string rather than the system's real parameters. GA employs an iterative process in which each iteration step three genetic factors (selection, crossover, and mutation) are applied to enhance the new selection of populations [3]. In Table 5, the most important scientific contributions in this field were explained:

Table 5. The GA approaches are used for solving the OPF problem.

\begin{tabular}{|c|c|c|c|c|}
\hline $\begin{array}{l}\text { Ref. } \\
\text { No. }\end{array}$ & year & objective function & system & Scientific contribution \\
\hline$[24]$ & 2005 & $\begin{array}{l}\text { fuel cost, } \mathrm{P} \text { losses, } \\
\text { and computing time }\end{array}$ & $\begin{array}{l}\text { the electrical } \\
\text { network in } \\
\text { western Algeria }\end{array}$ & $\begin{array}{l}\text { The Lagrange approach was used to } \\
\text { construct a genetic algorithm solution in this } \\
\text { paper. }\end{array}$ \\
\hline$[25]$ & 2007 & fuel cost, $\mathrm{P}$ losses & $\begin{array}{l}\text { the modified } \\
\text { IEEE } 57 \text { bus } \\
\text { test system }\end{array}$ & $\begin{array}{l}\text { To deal with OPF, a hybrid method is } \\
\text { applied such as GA and mat power including } \\
\text { the both active and reactive power } \\
\text { dispatching. }\end{array}$ \\
\hline$[26]$ & 2010 & $\begin{array}{l}\text { fuel cost, } \mathrm{P} \text { losses } \\
\text { and } \\
\text { voltage stability } \\
\text { enhancement }\end{array}$ & $\begin{array}{l}\text { IEEE } 30 \text { bus } \\
\text { system }\end{array}$ & $\begin{array}{l}\text { The DQLF method is applied that is } \\
\text { combined with an enhanced genetic } \\
\text { algorithm to solve the OPF problem. }\end{array}$ \\
\hline [27] & 2014 & $\begin{array}{l}\text { minimization of } \\
\text { cost, } \mathrm{P} \text { losses, and } \\
\text { emission }\end{array}$ & $\begin{array}{l}\text { IEEE 30-bus } \\
\text { test system }\end{array}$ & $\begin{array}{l}\text { considers fuel cost and emission functions } \\
\text { and proposes a solution to the severely } \\
\text { constrained multi-objective involving } \\
\text { competing objectives. }\end{array}$ \\
\hline [28] & 2018 & fuel cost, $\mathrm{P}$ losses & $\begin{array}{l}\text { two test } \\
\text { systems, } 15 \\
\text { benchmark } \\
\text { functions }\end{array}$ & $\begin{array}{l}\text { designs and suggests a real-coded genetic } \\
\text { algorithm that is more efficient. }\end{array}$ \\
\hline
\end{tabular}


In conclusion, we discover that GA has a number of advantages and downsides, which are briefly listed below:

\section{Advantages:}

1. GA avoids the trap of local optimality, they can deliver a globally optimal solution.

2. GA can solve non-smooth, non-continuous, and non-convex problems.

3. Changeable, with the ability to create a large number of solutions and a fast convergence.

\section{Disadvantages:}

1. GA are stochastic algorithms which means that the solution isn't always optimal.

2. With increasing chromosomal length the run period and accuracy of the solution decrease.

3. Once the system model goes bigger, the GA might lead to a waste of computing efforts.

\subsubsection{Particle Swarm Optimization (PSO) Method}

PSO is a population-based stochastic optimization method. It is a natural phenomena like as bird flocks and fish schools that occur in socially organised colonies. PSO employs a crew of individuals to scour the search space for promising regions [3]. In Table 6, the most important scientific contributions in this field were explained :

Table 6. The person approaches are used for solving the OPF problem.

\begin{tabular}{|c|c|c|c|c|}
\hline $\begin{array}{l}\text { Ref } \\
\text {.No. }\end{array}$ & year & objective function & system & Scientific contribution \\
\hline [29] & 2002 & $\begin{array}{l}\text { fuel cost, voltage } \\
\text { deviation, and } \\
\text { voltage stability }\end{array}$ & $\begin{array}{l}\text { standard IEEE 30- } \\
\text { bus test systems }\end{array}$ & $\begin{array}{l}\text { For the best position of OPF problem } \\
\text { control variables, the PSO method is } \\
\text { utilised. }\end{array}$ \\
\hline$[30]$ & 2013 & fuel cost, $\mathrm{P}$ losses & $\begin{array}{l}\text { IEEE } 14 \text { and } 30 \text { bus } \\
\text { test systems. }\end{array}$ & $\begin{array}{l}\text { To identify the lowest generation cost } \\
\text { values, this innovative approach adds } \\
\text { PSO to the Newton Raphson method. }\end{array}$ \\
\hline [31] & 2015 & $\begin{array}{l}\text { Fuel cost, P } \\
\text { Losses, and L- } \\
\text { index }\end{array}$ & $\begin{array}{l}\text { standard IEEE } 30- \\
\text { bus test system }\end{array}$ & $\begin{array}{l}\text { Particle Swarm Optimization (PSO) was } \\
\text { used to tackle the optimization problem } \\
\text { for the FACTS device's power injection } \\
\text { model. }\end{array}$ \\
\hline [32] & 2020 & $\begin{array}{l}\text { Cost }(\$ / h), P \text { loss } \\
(\mathrm{MW}), \mathrm{VD} \text { and } \mathrm{L} \\
\max \end{array}$ & $\begin{array}{l}\text { standard IEEE } 30 \\
\text { and } 57 \text { bus test } \\
\text { systems }\end{array}$ & $\begin{array}{l}\text { A multi-objective hybrid firefly and } \\
\text { PSO (MOHFPSO) was developed for } \\
\text { various multi-objective optimal power } \\
\text { flow (MOOPF) challenges. }\end{array}$ \\
\hline [33] & 2020 & $\begin{array}{l}\text { Fuel cost, P } \\
\text { Losses, VD and } \\
\text { L-index }\end{array}$ & $\begin{array}{l}\text { tested for IEEE } 9 \\
\text { and } 30 \text { bus systems }\end{array}$ & $\begin{array}{l}\text { The reactive power is solved using the } \\
\text { PSO method and the MATPOWER } 6.0 \\
\text { toolbox. }\end{array}$ \\
\hline
\end{tabular}


In summary, PSO could be briefly summarized by:

\section{Advantages:}

1. Capable of solving non-convex optimization problems on a large scale, such as OPF.

2. Simple concept, simple implementation, relative control parameter robustness, computing efficiency, and fast convergence speed.

3. Flexibility in balancing global and local search space exploration.

\section{Disadvantage:}

1. Slow convergence in detailed search stage (local search capability is limited).

\subsubsection{Ant Colony Optimization (ACO) Method}

It is based on ant foraging and the creation of a trail utilising pheromone communication. ACO is distinguished by using a probabilistic model to provide optimum solutions at hand [34]. In Table 7, the most important scientific contributions in this field were explained:

Table 7. The ACO approaches are used for solving the OPF problem.

\begin{tabular}{|c|c|c|c|c|}
\hline $\begin{array}{l}\text { Ref } \\
\text {.No. }\end{array}$ & year & objective function & system & Scientific contribution \\
\hline [35] & 2004 & $\begin{array}{l}\text { Generating cost, } \\
\text { Total cost }\end{array}$ & $\begin{array}{l}\text { A universal } \\
\text { moment } \\
\text { generating } \\
\text { function } \\
\text { (UMGF), three } \\
\text { and ten } \\
\text { generating units }\end{array}$ & $\begin{array}{l}\text { A suggested ant colony optimization method } \\
\text { with stochastic disruption activity (RPACO) } \\
\text { with randomised technique towards the Unit } \\
\text { commitment (UC) with stochastic spinning } \\
\text { reserve calculation. }\end{array}$ \\
\hline [36] & 2013 & $\begin{array}{l}\text { the voltage } \\
\text { stability }\end{array}$ & $\begin{array}{l}\text { WSCC 9-bus } \\
\text { test system. }\end{array}$ & $\begin{array}{l}\text { The voltage stability margin feature was } \\
\text { introduced and put into the load target function } \\
\text { of an OPF using an ACS method. }\end{array}$ \\
\hline [37] & 2016 & $\begin{array}{l}\text { the total fuel cost } \\
\text { and ecological } \\
\text { emission }\end{array}$ & $\begin{array}{l}\text { an IEEE } 30 \text { and } \\
118 \text { bus test } \\
\text { system }\end{array}$ & $\begin{array}{l}\text { The ideal power flow with ecological emission } \\
\text { is resolved using an enhanced ant colony } \\
\text { optimization technique. }\end{array}$ \\
\hline [38] & 2020 & $\begin{array}{l}\text { Power losses and } \\
\text { Cost }\end{array}$ & $\begin{array}{l}\text { the IEEE } 30 \text { and } \\
\text { the IEEE } 57 \text { bus } \\
\text { test cases }\end{array}$ & $\begin{array}{l}\text { shows the use of mixed-integer AC optimization } \\
\text { for power grid. }\end{array}$ \\
\hline [39] & 2020 & $\begin{array}{l}\text { fuel cost, } \mathrm{p} \text { losses } \\
\text { and voltage } \\
\text { deviation }\end{array}$ & $\begin{array}{l}\text { the IEEE-30 bus } \\
\text { system }\end{array}$ & $\begin{array}{l}\text { OPF is also solved using AC with single target } \\
\text { function based on constraints. }\end{array}$ \\
\hline
\end{tabular}

In summary, we find that ACO has several advantages and disadvantages which are mentioned briefly as follows:

\section{Advantages:}

1. Intelligent search, global optimization, dependability, and positive feedback are all features. 
2. Has the ability to compete with other optimization techniques.

3. The computational operators of the ACO algorithm are simple, with no crossover or mutation, resulting in low memory and calculation costs.

4. ACO is a gene selection that has the benefit of being able to be combined with other algorithms.

\section{Disadvantages:}

1. The convergence rate is very slow.

2. Over time, the pheromone gets overpowered.

3. It is simple to fall in the local optimal.

4. Theoretical analysis is difficult [40].

\subsubsection{Fuzzy Logic (FL) Method}

Fuzzy logic is based on fuzzy set theory, which deals with approximate rather than precise reasoning. It is utilised to solve the problem of load flow, resulting in a significant reduction in processing time. To express inexact relationships FL theory is a easy and appropriate tool [41]. In Table 8, the most important scientific contributions in this field were explained:

Table 8. The FL approaches are used for solving the OPF problem.

\begin{tabular}{|c|c|c|c|c|}
\hline $\begin{array}{l}\text { Ref. } \\
\text { No. }\end{array}$ & year & objective function & system & Scientific contribution \\
\hline [42] & 1992 & $\begin{array}{l}\text { cost of energy } \\
\text { generation }\end{array}$ & $\begin{array}{l}\text { very small } \\
\text { system the } \\
6 \text { bus/6 } \\
\text { branch } \\
\text { network }\end{array}$ & $\begin{array}{l}\text { presented a fuzzy model to describe load and } \\
\text { generation uncertainty as fuzzy numbers. }\end{array}$ \\
\hline [43] & 1997 & $\begin{array}{l}\text { operating cost and } \\
\text { correction times }\end{array}$ & $\begin{array}{l}\text { 14-bus } \\
\text { system }\end{array}$ & $\begin{array}{l}\text { the creation of fuzzy membership functions and } \\
\text { their objectives using a mechanism for } \\
\text { expressing the tolerance parameters required. }\end{array}$ \\
\hline [44] & 2004 & $\begin{array}{l}\text { percentage Real } \\
\text { and Reactive } \\
\text { power curtailment } \\
\text { and per unit } \\
\text { generation cost }\end{array}$ & $\begin{array}{l}\text { modified } \\
\text { IEEE } 30 \text { bus } \\
\text { test system }\end{array}$ & $\begin{array}{l}\text { An effective and practical mixture model for } \\
\text { overcrowding management for active and } \\
\text { reactive power transactions has been created in } \\
\text { the deregulated fuzzy environment of the power } \\
\text { system. }\end{array}$ \\
\hline [45] & 2010 & $\begin{array}{l}\text { Fuel cost and } \\
\text { emissions }\end{array}$ & $\begin{array}{l}\text { the IEEE } \\
\text { 14-bus } \\
\text { system }\end{array}$ & $\begin{array}{l}\text { the use of a fuzzy model to obtain a Pareto curve } \\
\text { that reflects the (tradeoff) between two } \\
\text { competing objectives. }\end{array}$ \\
\hline [46] & 2013 & $\begin{array}{l}\text { voltage deviations } \\
\text { and Network } \\
\text { Constraints }\end{array}$ & $\begin{array}{l}\text { thestandardI } \\
\text { EEE30- } \\
\text { bustestsyste } \\
\mathrm{m}\end{array}$ & $\begin{array}{l}\text { introduce a new controller architecture that uses } \\
\text { AFLC and SFLC techniques to regulate VAR } \\
\text { flow in the power system network. A simulation } \\
\text { software is used to introduce and test an adaptive } \\
\text { fuzzy set. }\end{array}$ \\
\hline
\end{tabular}

In summary, we find that FL has several outcomes such as:

Advantages: 
1. As a result, a fuzzy multi-objective approach like this is appealing for such problems in terms of cost and emissions.

2. Ease of use and flexibility, as well as a lower cost of development.

3 . Is capable of modeling nonlinear functions of any complexity.

4. Has the ability to deal with data that is inaccurate or incomplete.

\section{Disadvantages:}

1- A large number of calculations are required on account of the matrix.

2- When large-scale networks exist, a straightforward implementation of these approaches becomes inefficient resulting in increased memory requirements and computational time [41].

\subsubsection{Differential Evolution (DE) Method}

$\mathrm{DE}$ is a direct random search technique that is based on a population. To get from a random starting population to a final solution, it combines simple arithmetic operators with the conventional evolutionary operators of crossover, mutation, and selection. It uses a greedy strategy rather than a stochastic method to solve the problem [3]. In Table 9, the most important scientific contributions in this field were explained:

Table 9. The DE approaches are used for solving the OPF problem.

\begin{tabular}{|c|c|c|c|c|}
\hline $\begin{array}{l}\text { Ref } \\
\text {.No. }\end{array}$ & year & objective function & system & Scientific contribution \\
\hline$[47]$ & 2007 & $\begin{array}{l}\text { the total fuel cost } \\
\text { and P losses }\end{array}$ & $\begin{array}{l}\text { two test } \\
\text { systems }\end{array}$ & $\begin{array}{l}\text { Proposes improved DE approaches for } \\
\text { tackling the problem of economic load } \\
\text { dispatch. }\end{array}$ \\
\hline [48] & 2008 & $\begin{array}{l}\text { fuel cost and } \\
\text { transmission losses }\end{array}$ & $\begin{array}{l}\text { 6-bus and } \\
\text { IEEE } 30 \text { bus } \\
\text { systems }\end{array}$ & $\begin{array}{l}\text { MDE technique to achieve optimal power flow } \\
\text { (OPF). }\end{array}$ \\
\hline [49] & 2012 & $\begin{array}{l}\text { fuel cost, } P \text { losses, } \\
\text { and L-index }\end{array}$ & $\begin{array}{l}\text { IEEE } 30 \text { and } \\
118 \text { bus } \\
\text { systems }\end{array}$ & $\begin{array}{l}\text { provides a multi-objective differential } \\
\text { evolution-based method for OPF. }\end{array}$ \\
\hline$[50]$ & 2018 & $\begin{array}{l}\text { cost, power loss } \\
\text { emission, voltage } \\
\text { deviation and } \\
\text { stability }\end{array}$ & $\begin{array}{l}\text { IEEE } 30,57 \\
\text { and } 118 \text { bus } \\
\text { systems }\end{array}$ & $\begin{array}{l}\text { This research assesses the performance of } \\
\text { appropriate } \mathrm{CH}, \mathrm{SF}, \mathrm{SP} \text {, and joint of two of } \\
\text { these. }\end{array}$ \\
\hline [51] & 2020 & $\begin{array}{l}\text { fuel cost, } P \text { losses, } \\
\mathrm{Vd} \text {, the emission, } \\
\text { and the generation } \\
\text { and emission cost }\end{array}$ & $\begin{array}{l}\text { IEEE30-bus } \\
\text { test system }\end{array}$ & $\begin{array}{l}\text { A self-adaptive penalty constraint handling } \\
\text { system with improved adaptive differential } \\
\text { evolution (JADE). }\end{array}$ \\
\hline
\end{tabular}

In conclusion, we discover that DE offers a number of benefits and drawbacks, which are briefly discussed below:

\section{Advantages:}


1. When evaluated, it outperformed search heuristics.

2. It is a simple and effective evolutionary approach for optimising continuous-space functions.

3. The DE algorithm is a method for dealing with objective functions that are nondifferentiable, non-linear, and multimodal.

4. It can search at random, requires fewer parameters to set is fast, and can be utilised to solve high-dimensional difficult optimization problems.

\section{Disadvantages:}

1. The DE has a number of drawbacks, including lengthy operations, stagnation, and poor searchability.

2. Takes into account recent times of unstable convergence and the ease with which a regional optimum could be reached [52].

\subsubsection{Grey Wolf Optimizer (GWO) Method}

heuristics method is applied by GWO, which helps us understand Gray wolf hunting technique and leadership structure. Omega wolves are preceded by scoffed kappa and lambda wolves, whereas alpha wolves make decisions, beta wolves help alpha wolves, delta wolves are the lowest, and sneered kappa and lambda wolves are the highest [3]. Table 10 summarises the most significant scientific achievements in this field:

Table 10. The GWO approaches are used for solving the OPF problem

\begin{tabular}{|c|c|c|c|c|}
\hline $\begin{array}{l}\text { Ref } \\
\text {.No. }\end{array}$ & year & $\begin{array}{l}\text { objective } \\
\text { function }\end{array}$ & system & Scientific contribution \\
\hline [53] & 2015 & $\begin{array}{l}\text { the total } \\
\text { transmission } \\
\text { loss, and } \\
\text { voltage } \\
\text { deviation }\end{array}$ & $\begin{array}{l}\text { IEEE } 30 \\
\text { and } 118 \\
\text { bus } \\
\text { systems }\end{array}$ & $\begin{array}{l}\text { Best control elements are updated by GWO such as } \\
\text { generator voltages, tap changing transformer ratios, } \\
\text { and the number of reactive compensation devices. }\end{array}$ \\
\hline$[54]$ & 2016 & $\begin{array}{l}\text { cost, Emission, } \\
\text { total generation } \\
(\mathrm{MW}) \text {, and } \\
\text { percentage of } \\
\text { losses }\end{array}$ & $\begin{array}{l}\text { IEEE } 30 \\
\text { bus } \\
\text { system }\end{array}$ & $\begin{array}{l}\text { Modifications to the exploration-exploitation } \\
\text { balance in the original GWO algorithms, which } \\
\text { search the solution space with a random localization, } \\
\text { have been suggested for high-quality solutions. }\end{array}$ \\
\hline$[55]$ & 2017 & $\begin{array}{l}\mathrm{P} \text { loss }(\mathrm{MW}) \\
\text { and total cost }\end{array}$ & $\begin{array}{l}\text { IEEE 30- } \\
\text { bus test } \\
\text { system. }\end{array}$ & $\begin{array}{l}\text { The method is used to address the optimal power } \\
\text { flow (OPF) problem in a system incorporating wind } \\
\text { farms in order to reduce power grid losses and power } \\
\text { production costs. }\end{array}$ \\
\hline$[56]$ & 2018 & $\begin{array}{l}\text { quadratic fuel } \\
\text { cost, } \mathrm{P} \text { loss, L- } \\
\text { index, and Vd }\end{array}$ & $\begin{array}{l}\text { IEEE 30- } \\
\text { bus. }\end{array}$ & $\begin{array}{l}\text { The DGWO algorithm is proposed to improve this } \\
\text { optimizer's search capabilities (DGWO). }\end{array}$ \\
\hline$[57]$ & 2020 & $\begin{array}{l}\text { fuel cost, } \mathrm{P} \\
\text { losses, and } \mathrm{L}- \\
\text { index and } \mathrm{Vd}\end{array}$ & $\begin{array}{l}\text { IEEE } 30 \\
\text { bus. }\end{array}$ & $\begin{array}{l}\text { ORPD problems are computed using a unique } \\
\text { nature-inspired metaheuristic optimization approach } \\
\text { based on the Grey Wolf Optimization (GWO) } \\
\text { algorithm. }\end{array}$ \\
\hline
\end{tabular}


In conclusion, we discover that GWO offers a number of benefits and drawbacks, which are briefly listed below:

\section{Advantages:}

1. Its ability to solve OPF problems in both single- and multi-objective optimization domains.

2. Due to its basic structure, it is straightforward to apply.

3. Requirements for storage and computation are reduced.

4. Convergence occurs faster since the search space is always shrinking and there are fewer choice criteria.

5. It is the capacity to avoid local minima and govern algorithm performance with only two control parameters, resulting in increased stability and robustness [58].

\section{Disadvantages:}

1. There is a lack of precision in solving problems.

2. Inadequate local search capability.

3. A slow rate of convergence [59].

\subsubsection{Shuffled Frog- Leaping (SFLA) Method}

To find a globally optimal solution, SFLA employs a heuristic search based on the evolution of memes carried by individuals and global information flow. It combines the advantages of PSM's local search tool with the concept of combining data from several local searches to arrive at a global solution (3). In Table 11, the most important scientific contributions in this field were explained:

Table 11. The SFLA approaches are used for solving the OPF problem.

\begin{tabular}{|c|c|c|c|c|}
\hline $\begin{array}{l}\text { Ref } \\
\text {.No. }\end{array}$ & year & $\begin{array}{l}\text { objective } \\
\text { function }\end{array}$ & system & Scientific contribution \\
\hline$[60]$ & 2011 & total cost & $\begin{array}{l}\text { standard IEEE - } \\
\text { 30bus system }\end{array}$ & $\begin{array}{l}\text { Proposed a new way for distributing the power } \\
\text { optimal distribution based on a shuffling frog } \\
\text { jumping algorithm. }\end{array}$ \\
\hline$[61]$ & 2017 & $\begin{array}{l}\text { total loss, total } \\
\text { cost, and the } \\
\text { Vd }\end{array}$ & $\begin{array}{l}\text { IEEE } 33 \text { and } 69 \\
\text { bus test systems }\end{array}$ & $\begin{array}{l}\text { For optimal DG placement in the distribution } \\
\text { system, the shuffled frog leaping algorithm } \\
\text { (SFLA) is used. }\end{array}$ \\
\hline$[62]$ & 2018 & P loss & $\begin{array}{l}\text { the IEEE33 node } \\
\text { distribution } \\
\text { system }\end{array}$ & $\begin{array}{l}\text { A reconfiguration algorithm for a distribution } \\
\text { network based on an improved shuffling frog } \\
\text { leaping algorithm was developed using } \\
\text { molecular dynamics theory and cloud } \\
\text { simulation theory. }\end{array}$ \\
\hline$[63]$ & 2021 & P loss & $\begin{array}{l}\text { standard IEEE } \\
14,300 \text { bus test } \\
\text { system }\end{array}$ & $\begin{array}{l}\text { The best frog information is used to augment } \\
\text { the local search in each iteration of the } \\
\text { proposed Advanced Frog Leaping Algorithm } \\
\text { (EFLA). }\end{array}$ \\
\hline
\end{tabular}

In summary, we find that SFLA has some unique operational outcome in terms of 


\section{Advantages:}

1. It adds the benefits of PSM's local search tool with the idea of merging data from multiple local searches to get a global solution.

\section{Disadvantage:}

1. Slow convergence, It's easy to get caught up in the local best answer, which leads to premature convergence.

Traditional methodologies are not always adequate and cannot guarantee a global solution since $\mathrm{OPF}$ issues are multimodal, nonlinear, or non-convex; therefore many heuristic methods were applied. By looking at the past studies stated above, the benefits of new optimization approaches may be summarized as follows:

1. These techniques can be used in systems of various sizes are available.

2. High dependability in obtaining the optimum solutions in a single simulation run.

3. These techniques rarely resulted in local minimum solutions.

4. When compared to traditional methods, these techniques converge quickly to the optimum solution.

5. Suitable in solving multi-objective optimization problems.

6. Able to handle various qualitative constraints.

\section{CONCLUSION}

This study examines a variety of optimization techniques for tackling OPF issues, including both classic and intelligent approaches. Even if classical methods have made significant progress, they still have drawbacks. For example, due to the relatively limited ability to handle real-world large-scale power system problems so mathematical formulations must be simplified to obtain solutions. Some needed linearization and differentiability may become entangled at a locally optimal. have poor convergence are ineffective in dealing with qualitative constraints and will be very slow if there are a lot of variables. But the main benefit of artificial intelligence approaches is their adaptability in organizing different qualitative constraints. The optimum solution can be performed using AI approaches in one computation. In the vast majority global solution can be approached. In this survey, the benefits and drawbacks of artificial intelligence methods were discussed. Also in this Paper, various popular techniques in optimum power flow researchers' contributions to each methodology have been presented clearly and concisely.

\section{References}

[1] A. Immanuel and C. Chengaiah, "A Comprehensive Literature Survey on Recent Methods of Optimal Power Flow," IOSR J. Electr. Electron. Eng. Ver. II, vol. 10, no. 5, pp. 2278-1676, 2015, doi: 10.9790/1676-10520112.

[2] M. Ebeed, S. Kamel, and F. Jurado, Optimal power flow using recent optimization techniques, no. June. Elsevier Inc., 2018.

[3] A. Khamees, N. Badra, and A. Abdelaziz, "Optimal Power Flow Methods: A Comprehensive Survey," Ieejournal.Com, vol. 7, no. 4, pp. 2228-2239, 2016, [Online]. Available: http://www.ieejournal.com/wp-content/uploads/Volume/Vol 7 No 4/Optimal Power Flow Methods A Survey.pdf. 
[4] T. S. Chung and G. Shaoyun, "A recursive LP-based approach for optimal capacitor allocation with cost-benefit consideration," Electr. Power Syst. Res., vol. 39, no. 2, pp. 129-136, 1996, doi: 10.1016/S0378-7796(96)01103-0.

[5] E. Lobato, L. Rouco, M. I. Navarrete, R. Casanova, and G. López, “An LP-based optimal power flow for transmission losses and generator reactive margins minimization," 2001 IEEE Porto Power Tech Proc., vol. 3, pp. 121-125, 2001, doi: 10.1109/PTC.2001.964894.

[6] F. G. M. Lima, F. D. Galiana, I. Kockar, and J. Munoz, "Phase shifter placement in large-scale systems via mixed integer linear programming," IEEE Trans. Power Syst., vol. 18, no. 3, pp. 1029-1034, 2003, doi: 10.1109/TPWRS.2003.814858.

[7] Mukherjee, Srijib K., Agustin Recio, and Christos Douligeris. "Optimal power flow by linear programming based optimization." Proceedings IEEE Southeastcon'92. IEEE, 1992.

[8] F. M. Tuaimah and M. F. Meteb, "A Linear Programming Method Based Optimal Power Flow Problem for Iraqi Extra High Voltage Grid (EHV),” J. Eng., vol. 20, no. 4, pp. 23-35, 2014.

[9] J. Zhu and J. A. Momoh, "Multi-area power systems economic dispatch using nonlinear convex network flow programming," Electr. Power Syst. Res., vol. 59, no. 1, pp. 13-20, 2001, doi: 10.1016/S0378-7796(01)00131-6.

[10] A. K. Sharma, "Optimal number and location of TCSC and loadability enhancement in deregulated electricity markets using MINLP," Int. J. Emerg. Electr. Power Syst., vol. 5, no. 1, pp. 1-15, 2006, doi: 10.2202/1553-779X.1117.

[11] G. L. Torres, "Smooth, non-smooth and Jacobian smoothing nonlinear complementarity methods for solving optimal power flows," no. December, 2014.

[12] D. Pudjianto, S. Ahmed, and G. Strbac, "Allocation of VAr support using LP and NLP based optimal power flows," IEE Proc. Gener. Transm. Distrib., vol. 149, no. 4, pp. 377-383, 2002, doi: 10.1049/ip-gtd:20020200.

[13] A. M. Sasson, "Decomposition Techniques Applied to the Nonlinear Programming Load-Flow Method," IEEE Trans. Power Appar. Syst., vol. PAS-89, no. 1, pp. 78-82, 1970, doi: 10.1109/TPAS.1970.292671.

[14] Momoh, James A. "A generalized quadratic-based model for optimal power flow." Conference Proceedings., IEEE International Conference on Systems, Man and Cybernetics. IEEE, 1989.

[15] N. Grudinin, "Reactive power optimization using successive quadratic programming method," IEEE Trans. Power Syst., vol. 13, no. 4, pp. 1219-1225, 1998, doi: 10.1109/59.736232.

[16] G. P. Granelli and M. Montagna, "Security-constrained economic dispatch using dual quadratic programming," Electr. Power Syst. Res., vol. 56, no. 1, pp. 71-80, 2000, doi: 10.1016/S03787796(00)00097-3.

[17] Lin, X., A. K. David, and C. W. Yu. "Reactive power optimisation with voltage stability consideration in power market systems." IEE Proceedings-Generation, Transmission and Distribution 150.3 (2003): 305-310.

[18] A. Berizzi, M. Delfanti, P. Marannino, M. S. Pasquadibisceglie, and A. Silvestri, "Enhanced security-constrained OPF with FACTS devices," IEEE Trans. Power Syst., vol. 20, no. 3, pp. 1597-1605, 2005, doi: 10.1109/TPWRS.2005.852125.

[19] X. Ding, X. Wang, Y. Song, and J. Geng, “The interior point branch and cut method for optimal power flow," PowerCon 2002 - 2002 Int. Conf. Power Syst. Technol. Proc., vol. 1, pp. 651-655, 2002, doi: 10.1109/ICPST.2002.1053623.

[20] E. D. Castronuovo, R. Salgado, and J. M. Campagnolo, "New Versions of Interior Point Methods 
Applied to the Optimal Power FlowProblem,” no. June 2014, pp. 1-6, 2001.

[21] F. Capitanescu, M. Glavic, and L. Wehenkel, "An interior-point method based optimal power flow,” Proc. ACOMEN Conf., no. June 2005, pp. 1-18, 2005.

[22] W. Yan, J. Yu, D. C. Yu, and K. Bhattarai, "A new optimal reactive power flow model in rectangular form and its solution by predictor corrector primal dual interior point method," IEEE Trans. Power Syst., vol. 21, no. 1, pp. 61-67, 2006, doi: 10.1109/TPWRS.2005.861978.

[23] J. Mandi and T. Guns, "Interior Point Solving for LP-based prediction+optimisation," no. NeurIPS, 2020, [Online]. Available: http://arxiv.org/abs/2010.13943.

[24] R. Ouiddir, M. Rahli, and L. Abdelhakem-Koridak, "Economic dispatch using a genetic algorithm: Application to western Algeria's electrical power network," J. Inf. Sci. Eng., vol. 21, no. 3, pp. 659-668, 2005.

[25] M. Younes, M. Rahli, and L. Abdelhakem-Koridak, "Optimal Power Flow based on Hybrid Genetic Algorithm," J. Inf. Sci. Eng., vol. 23, no. 6, pp. 1801-1816, 2007, doi: 10.6688/JISE.2007.23.6.10.

[26] M. S. Kumari and S. Maheswarapu, "Enhanced Genetic Algorithm based computation technique for multi-objective Optimal Power Flow solution," Int. J. Electr. Power Energy Syst., vol. 32, no. 6, pp. 736-742, 2010, doi: 10.1016/j.ijepes.2010.01.010.

[27] H. Aliyari, R. Effatnejad, and M. Savaghebi, "Economic Dispatch With Genetic Algorithm," ICTPE Conf., no. September, pp. 82-87, 2014.

[28] J. K. Pattanaik, M. Basu, and D. P. Dash, "Improved real coded genetic algorithm for dynamic economic dispatch,” J. Electr. Syst. Inf. Technol., vol. 5, no. 3, pp. 349-362, 2018, doi: 10.1016/j.jesit.2018.03.002.

[29] M. A. Abido, "Optimal power flow using particle swarm optimization," Int. J. Electr. Power Energy Syst., vol. 24, no. 7, pp. 563-571, 2002, doi: 10.1016/S0142-0615(01)00067-9.

[30] B. E. Turkay and R. I. Cabadag, "Optimal power flow solution using particle swarm optimization algorithm," IEEE EuroCon 2013, no. July, pp. 1418-1424, 2013, doi: 10.1109/EUROCON.2013.6625164.

[31] J. Praveen and B. S. Rao, "Single objective optimization using PSO with Interline Power Flow Controller," no. November, 2016.

[32] A. Khan, H. Hizam, N. I. Abdul-Wahab, and M. L. Othman, "Solution of optimal power flow using non-dominated sorting multi objective based hybrid firefly and particle swarm optimization algorithm," Energies, vol. 13, no. 6, 2020, doi: 10.3390/en13164265.

[33] M. T. Rabadiya and V. B. Patel, "REVIEW ON REACTIVE POWER DISPATCH USING PARTICLE SWARM OPTIMIZATION ( PSO ) AND GREY WOLF OPTIMIZER,” vol. 7, no. 8, pp. 6674-6680, 2020.

[34] L. Slimani and T. Bouktir, "An Ant colony optimization for solving the Optimal Power Flow Problem in medium-scale electrical network," no. November 2014, 2005, doi: 10.13140/2.1.3402.2088.

[35] L. Shi, J. Hao, J. Zhou, and G. Xu, “Ant colony optimization algorithm with random perturbation behavior to the problem of optimal unit commitment with probabilistic spinning reserve determination," Electr. Power Syst. Res., vol. 69, no. 2-3, pp. 295-303, 2004, doi: 10.1016/j.epsr.2003.10.008.

[36] L. Kanagasabai, B. R. Reddy, and M. S. Kalavathi, "Optimal Power Flow using Ant Colony Search Algorithm to Evaluate Load Curtailment Incorporating Voltage Stability Margin 
Criterion,” Int. J. Electr. Comput. Eng., vol. 3, no. 5, 2013, doi: 10.11591/ijece.v3i5.2738.

[37] V. Raviprabakaran and R. C. Subramanian, "Enhanced ant colony optimization to solve the optimal power flow with ecological emission," Int. J. Syst. Assur. Eng. Manag., vol. 9, no. 1, pp. 58-65, 2018, doi: 10.1007/s13198-016-0471-x.

[38] V. Suresh, P. Janik, and M. Jasinski, "Metaheuristic approach to optimal power flow using mixed integer distributed ant colony optimization," Arch. Electr. Eng., vol. 69, no. 2, pp. 335-348, 2020, doi: $10.24425 /$ aee.2020.133029.

[39] A. Qasim and L. Tawfeeq Al-Bahrani, "Constraint Optimal Power Flow Based on Ant Colony Optimization,” J. Eng. Sustain. Dev., vol. 24, no. Special, pp. 274-283, 2020, doi: 10.31272/jeasd.conf.1.30.

[40] L. Sun, X. Kong, J. Xu, Z. Xue, R. Zhai, and S. Zhang, “A Hybrid Gene Selection Method Based on ReliefF and Ant Colony Optimization Algorithm for Tumor Classification," Sci. Rep., vol. 9 , no. 1, pp. 1-14, 2019, doi: 10.1038/s41598-019-45223-x.

[41] Vlachogiannis, J. G. "Fuzzy logic application in load flow studies." IEE Proceedings-Generation, Transmission and Distribution 148.1 (2001): 34-40.

[42] Miranda, Vladimiro, and Joao P. Saraiva. "Fuzzy modelling of power system optimal load flow." IEEE Transactions on Power Systems 7.2 (1992): 843-849..

[43] J. J. Buckley and L. J. Jowers, "Fuzzy multiobjective LP," Stud. Fuzziness Soft Comput., vol. 222, no. 3, pp. 81-88, 2008, doi: 10.1007/978-3-540-76290-4_9.

[44] N. P. Padhy, "Congestion management under deregulated fuzzy environment," Proc. 2004 IEEE Int. Conf. Electr. Util. Deregulation, Restruct. Power Technol., vol. 1, no. April, pp. 133-139, 2004, doi: 10.1109/drpt.2004.1338481.

[45] V. C. Ramesh and X. Li, "Optimal power flow with fuzzy emissions constraints," Electr. Mach. Power Syst., vol. 25, no. 8, pp. 897-906, 1997, doi: 10.1080/07313569708955784.

[46] A. M. Abusorrah, "Optimal power flow using adaptive fuzzy logic controllers," Math. Probl. Eng., vol. 2013, no. August, 2013, doi: 10.1155/2013/975170.

[47] L. dos S. Coelho and V. C. Mariani, "Improved differential evolution algorithms for handling economic dispatch optimization with generator constraints," Energy Convers. Manag., vol. 48, no. 5, pp. 1631-1639, 2007, doi: 10.1016/j.enconman.2006.11.007.

[48] S. Sayah and K. Zehar, "Modified differential evolution algorithm for optimal power flow with non-smooth cost functions," Energy Convers. Manag., vol. 49, no. 11, pp. 3036-3042, 2008, doi: 10.1016/j.enconman.2008.06.014.

[49] M. A. Abido and N. A. Al-Ali, "Multi-Objective Optimal Power Flow Using Differential Evolution," Arab. J. Sci. Eng., vol. 37, no. 4, pp. 991-1005, 2012, doi: 10.1007/s13369-012-02243 .

[50] P. P. Biswas, P. N. Suganthan, R. Mallipeddi, and G. A. J. Amaratunga, "Optimal power flow solutions using differential evolution algorithm integrated with effective constraint handling techniques," Eng. Appl. Artif. Intell., vol. 68, pp. 81-100, 2018, doi: 10.1016/j.engappai.2017.10.019.

[51] S. Li, W. Gong, L. Wang, X. Yan, and C. Hu, "Optimal power flow by means of improved adaptive differential evolution," Energy, vol. 198, p. 117314, 2020, doi: 10.1016/j.energy.2020.117314.

[52] Y.-C. Wu, W.-P. Lee, and C.-W. Chien, "Modified the performance of differential evolution algorithm with dual evolution strategy," Int. Conf. Mach. Learn. Comput., vol. 3, pp. 57-63, 2009. 
[53] M. H. Sulaiman, Z. Mustaffa, M. R. Mohamed, and O. Aliman, "Using the gray wolf optimizer for solving optimal reactive power dispatch problem,” Appl. Soft Comput. J., vol. 32, pp. 286292, 2015, doi: 10.1016/j.asoc.2015.03.041.

[54] A. A. A. Mohamed, A. A. M. El-Gaafary, Y. S. Mohamed, and A. M. Hemeida, "Multi-objective Modified Grey Wolf Optimizer for Optimal Power Flow," 2016 18th Int. Middle-East Power Syst. Conf. MEPCON 2016 - Proc., pp. 982-990, 2017, doi: 10.1109/MEPCON.2016.7837016.

[55] M. Siavash, C. Pfeifer, A. Rahiminejad, and B. Vahidi, "An application of grey Wolf optimizer for optimal power flow of wind integrated power systems," Proc. 2017 18th Int. Sci. Conf. Electr. Power Eng. EPE 2017, 2017, doi: 10.1109/EPE.2017.7967230.

[56] M. Abdo, S. Kamel, M. Ebeed, J. Yu, and F. Jurado, "Solving non-smooth optimal power flow problems using a developed grey wolf optimizer," Energies, vol. 11, no. 7, pp. 1-16, 2018, doi: 10.3390/en11071692.

[57] R. Jamal, B. Men, and N. H. Khan, "A Novel Nature Inspired Meta-Heuristic Optimization Approach of GWO Optimizer for Optimal Reactive Power Dispatch Problems," IEEE Access, vol. 8, pp. 202596-202610, 2020, doi: 10.1109/ACCESS.2020.3031640.

[58] I. A. Hameed, R. T. Bye, and O. L. Osen, "Grey Wolf optimizer (GWO) for automated offshore crane design," 2016 IEEE Symp. Ser. Comput. Intell. SSCI 2016, 2017, doi: 10.1109/SSCI.2016.7849998.

[59] N. Singh, "A Modified Variant of Grey Wolf Optimizer," Sci. Iran., vol. 0, no. 0, pp. 0-0, 2018, doi: 10.24200/sci.2018.50122.1523.

[60] H. C. Nejad, "Applying Shuffled Frog Leaping Algorithm for Economic Load Dispatch of Power System," vol. 20, no. 20, pp. 82-89, 2011.

[61] M. C. V. Suresh and J. Belwin Edward, "Optimal placement of distributed generation in distribution systems by using shuffled frog leaping algorithm," ARPN J. Eng. Appl. Sci., vol. 12, no. 3, pp. 863-868, 2017.

[62] X. Dong, Z. Wu, L. Chen, Z. Liu, and X. Xu, "Distribution Network Reconfiguration Method with Distributed Generators Based on an Improved Shuffled Frog Leaping Algorithm," 2018 IEEE PES/IAS PowerAfrica, PowerAfrica 2018, pp. 102-107, 2018, doi: 10.1109/PowerAfrica.2018.8521095.

[63] K. Lenin, "Factual Power Loss Diminution by Enhanced Frog Leaping Algorithm," J. Appl. Sci. Eng. Technol. Educ., vol. 3, no. 2, pp. 114-118, 2020, doi: 10.35877/454ri.asci112. 